\title{
SALICYLIC ACID AS A SALINE STRESS ATTENUATOR IN THE PHYSIOLOGICAL QUALITY OF Erythrina velutina SEEDS
}

Jackson Silva Nóbrega ${ }^{2} \odot$, Toshik Iarley da Silva ${ }^{3 *} \odot$, Ronimeire Torres da Silva $^{4} \odot$, Maria de Fátima de Queiroz Lopes $^{2}$, ,Francisco Romário Andrade Figueiredo ${ }^{5}$ ? and Riselane de Lucena Alcântara Bruno ${ }^{2}$ (?)

\footnotetext{
${ }^{1}$ Received on 16.08.2020 accepted for publication on 30.03.2021.

${ }^{2}$ Universidade Federal da Paraíba, Programa de Pós-Graduação em Agronomia, Areia, PB - Brasil. E-mail: <jacksonnobrega@hotmail. com>, <fatimaqueiroz0@gmail.com> and <lanebruno.bruno@gmail.com>.

${ }^{3}$ Universidade Federal de Viçosa, Programa de Pós-Graduação em Fitotecnia, Viçosa, MG - Brasil. E-mail: <toshik.silva@ufv.br>.

${ }^{4}$ Universidade Federal da Paraíba, Doutora em Agronomia, Areia, PB - Brasil. E-mail: <ronimeiretorres@hotmail.com

${ }^{5}$ UniversidadeFederal Rural do Seminário,ProgramadePós-Graduaçãoem Fitotecnia,Mossoró,RN-Brasil.E-mail:<romarioagroecologia@ yahoo.com.br>

*Corresponding author.
}

\begin{abstract}
Salinity is one of the problems that limit plant development, with the germination, growth, and initial establishment stages being the most sensitive to saline stress. Erythrina velutina, popularly known as "mulungu" in Brazil, is a species native to the Caatinga biome, which grows in conditions of soil rich in salts. The damage caused by salinity to the quality of its seeds and the use of techniques that mitigate such effects are little known. Thus, this work aimed to evaluate salicylic acid as a mitigator of saline stress in the physiological quality of mulungu seeds. The quality of two seed lots from two Brazilian states (L1: Mossoró, Rio Grande do Norte, and L2: Pentencostes, Ceará) was evaluated. A completely randomized design in a 2 (seed soaking with salicylic acid (SA) - distilled water and $1.0 \mathrm{mM} \mathrm{SA}) \times 4$ (electrical conductivity of irrigation water $\mathrm{ECw}-0.0,3.0,6.0$ and $9.0 \mathrm{dS} \mathrm{m}^{-1}$ ) factorial scheme with four replications of 50 seeds each was used. Saline stress reduces the quality of mulungu seeds and seedlings. SA increases the vigor of the seeds, promoting improvements in germination under saline conditions.
\end{abstract}

Keywords: Caatinga; Phytohormone; Salinity.

\section{ÁCIDO SALICÍLICO COMO ATENUADOR DO ESTRESSE SALINO NA QUALIDADE FISIOLÓGICA DE SEMENTES DE Erythrina velutina}

RESUMO - A salinidade é um dos problemas que limitam o desenvolvimento das plantas, sendo as fases de germinação, crescimento e estabelecimento inicial as mais sensiveis ao estresse salino. Erythrina velutina, popularmente conhecida no Brasil como "mulungu", é uma espécie nativa do bioma Caatinga, que cresce em condições de solo rico em sais. Os danos causados pela salinidade à qualidade de suas sementes e a utilização de técnicas que mitiguem esses efeitos são pouco conhecidos. Assim, o objetivo deste trabalho foi avaliar o ácido salicílico como mitigador do estresse salino na qualidade fisiológica de sementes de mulungu. A qualidade de dois lotes de sementes de dois estados brasileiros (L1: Mossoró, Rio Grande do Norte, e L2: Pentencostes, Ceará) foi avaliada. O delineamento inteiramente casualizado em esquema fatorial 2 (embebição de sementes com ácido salicílico (SA) - água destilada e 1,0 mM SA) $\times 4$ (condutividade elétrica da água de irrigação - ECw - 0,0, 3,0, 6,0 e 9,0 dS $\mathrm{m}^{-1}$ ) com quatro repetições de 50 sementes cada foi usado. O estresse salino reduz a qualidade das sementes e mudas de mulungu. SA aumenta o vigor das sementes, promovendo melhorias na germinação em condições salinas.

Palavras-Chave: Caatinga; Fitohormônio; Salinidade.

SIIF $(c))$ EY
Revista Árvore 2021;45:e4521 http://dx.doi.org/10.1590/1806-908820210000021 


\section{INTRODUCTION}

Erythrina velutina Willd, popularly known as mulungu, is a xerophilous plant originating exclusively from the Caatinga biome, located in the semi-arid region of Brazil. This is a large arboreal plant with twisted stem, used commonly as wood, handicrafts, ornamental use and agroforestry systems, in addition to being used in the regeneration of degraded areas (Alves Junior et al., 2016; Teixeira et al., 2019). E. velutina seedlings are used in regeneration projects in degraded areas, as they have rapid growth and adaptive characteristics to the semiarid environment (Rodrigues et al., 2018). This plant is used in traditional medicine to treat psychotic disorders, due to the presence of alkaloids, terpenes and flavonoids, promoting neuroprotective, anxiolytic, sedative, anticonvulsant, antinociceptive and antioxidant effects (Dias et al., 2019).

Despite being a species found in arid and semiarid regions, such as the Brazilian Northeast, the high salt content of soil and irrigation water, typical of these regions, can compromise the development of this species. In addition, the water used in irrigation during the production of seedlings, being of low quality, affects the initial establishment of plants, making it difficult to obtain healthy seedlings and/or maintain their survival in the field (Ibrahim, 2016).

Among the stages of plant development, germination and initial seedling growth are critical stages for the establishment of most species, and these are periods in which they are very sensitive to saline stress (Ibrahim, 2016). High salinity inhibits germination due to a reduced water absorption capacity by the seed, toxicity of specific ions (such as $\mathrm{Na}^{+}$and $\mathrm{Cl}^{-}$) and changes in the biochemical reactions involved in the germination metabolism, which can lead to reduction and/or delay and death of seeds before germination (Anaya et al., 2018; Pereira et al., 2020).

The development of methods for minimizing the harmful effects of saline stress on plants is very important. Tolerance to salinity in plants can be increased by treating seeds with different osmotic solutions (phytohormones, sugars, inorganic salts and polyethylene glycol), a technique known as seed soaking (Akter et al., 2018). Among these solutions, salicylic acid stands out as a phytormone capable of increasing the tolerance of plants against the adverse effects of saline stress (Nóbrega et al., 2020).

The application of salicylic acid triggers tolerance to biotic and abiotic stresses in plants through the regulation of biochemical and physiological mechanisms, including ions, antioxidant enzymes, endogenous hormones and gene expression related to their synthesis (Kim et al., 2018). In addition, acclimatization to saline stress in plants can be improved by exclusion and/or compartmentalization of ions, osmoregulation, reduction of membrane lipid peroxidation, protein kinase synthesis, antioxidant system regulation, etc. (Yan et al., 2018).

Although soaking seeds with salicylic acid is an efficient technique for attenuating saline stress, little is known about its effect on the germination of forest species. Information on the use of salicylic acid in the germination of E. velutina is important for optimizing the production of good quality seedlings for use in reforestation projects, in the recovery of degraded areas in places with a loss of biodiversity, as well as for the acquisition of additional information about the use of salicylic acid in the germination of this species. Thus, the aim of this work was to evaluate salicylic acid as a mitigator of saline stress in the physiological quality of mulungu seeds.

\section{MATERIAL AND METHODS}

\subsection{Experiment Location}

The experiment was carried out at the Laboratório de Análise de Sementes - LAS (Seed Analysis Laboratory), at the Centro de Ciências Agrárias CCA (Center for Rural Sciences) of the Universidade Federal da Paraíba - UFPB (Federal University of Paraíba), Campus II, Areia, Paraíba, Brazil.

\subsection{Experimental design}

Two lots of mulungu (Erythrina velutina) seeds were used: Lot 1 (L1): collected in Mossoró, Rio Grande do Norte state, and Lot 2 (L2): collected in Pentecostes, Ceará state. The climate of the predominant region according to the Köppen-Geiger classification in both municipalities is hot semi-arid, divided into dry (prolonged) and wet (short and irregular) periods. The completely randomized design

Revista Árvore 2021;45:e4521 
in a factorial scheme of 2 (seed soaking - distilled water and $1.0 \mathrm{mM}$ salicylic acid) $\times 4$ (electrical conductivity of irrigation water $-\mathrm{ECw}=0.0,3.0,6.0$ and $9.0 \mathrm{dS} \mathrm{m}^{-1}$ ) with four replications of 50 seeds each was used.

\subsection{Preparation of soaking}

The seeds were soaked in $200 \mathrm{~mL}$ of distilled water and/or a solution of salicylic acid for 8 hours, under relative humidity and at room temperature. After soaking, the seeds were washed with distilled water to remove any excess salicylic acid. The saline waters were prepared by adding sodium chloride $(\mathrm{NaCl})$ to distilled water, with the values measured using an Instrutherm ${ }^{\circledR}$ portable conductivity meter, model CD-860. After soaking in this saline solution, the seeds from each lot were placed to germinate on rolls of paper moistened with water at pre-established levels of electrical conductivity of water, in an amount equivalent to 2.5 times the dry weight of the paper, and packed in BOD- (Biological Oxygen Demand) type germination chambers, with a constant temperature of $20{ }^{\circ} \mathrm{C}$ and a photoperiod of 8 hours (Brasil, 2009).

\subsection{Variables Analyzed}

The germination evaluations were carried out from the $5^{\text {th }}$ to the $15^{\text {th }}$ day after the beginning of the soaking, considering that the seeds that produced normal seedlings were considered to be germinated, that is, the ones that presented the primary root protrusion and emission of the leaf primordia. The germination speed index was obtained from the daily count of normal seedlings for 15 days, as established by the methodology of Maguire (1962). The average germination speed was determined from the count of germinated seeds during each day of the germination test and calculated according to Labouriau and Valadares (1976).

The root length, shoot length and seedling length were measured on the $15^{\text {th }}$ day of evaluation, with 10 seedlings per repetition. A ruler graduated in centimeters was used, considering the length from the root insertion to the seedling's apex, with the result expressed in $\mathrm{cm}$. The seedlings were placed in paper bags and dried in an oven at $65^{\circ} \mathrm{C}$ for 24 hours, after which they were weighed to evaluate the seedling dry matter mass, the result being expressed in $g$ per seedling.

\subsection{Statistical analysis}

The data was subjected to analysis of variance by the F test and, when significant, Tukey's test was applied at $5 \%$ probability to determine the difference between the seed lots. Canonical correspondence analysis and confidence ellipses $(p \leq 0.01)$ were performed to study the interrelationship between variables and factors. The candisc package (Friendly and Fox, 2017) and R statistical program (R Core Team 2020) were used.

\section{RESULTS}

The values of germination, first count and germination speed index were higher in the seeds of Lot 1, with a superiority of $61.5,60.8$ and 70.2\%, respectively (Table 1 ). The vigor represented by the root length, shoot length and seedling length was also higher in the seeds of Lot 1 . The average speed of germination was higher $(0.22)$ in the seeds of Lot 2 . The dry masses of the root, shoot and seedlings were not different between the seed lots (Table 1).

An analysis of canonical variables for mean scores of the first two canonical variables was used to verify the contribution of each variable to the difference between treatments (Figure 1). The dimensions of components 1 and 2 of Lot 1 (Mossoró) were 83.7

Table 1 - Germination percentage (GP), first count of germination (FCG), germination speed index (GSI), average germination speed (AGS), root dry mass (RDM), shoot dry mass (SDM), seedling dry mass (SEDM), shoot length (SL), root length (RL) and seedling length (SEL) of different seed lots of Erythrina velutina.

Tabela 1 - Porcentagem de germinação $(G P)$, primeira contagem de germinação (FCG), índice de velocidade de germinação (GSI), velocidade média de germinação (AGS), massa seca da raiz (RDM), massa seca da parte aérea (SDM), massa seca da muda (SEDM), comprimento do caule (SL), comprimento da raiz (RL) e comprimento da muda (SEL) de diferentes lotes de sementes de Erythrina velutina.

\begin{tabular}{|c|c|c|c|c|c|}
\hline \multirow[t]{2}{*}{$\overline{\text { Lote }}$} & GP & $\overline{\mathrm{FCG}}$ & GSI & $\mathrm{AGS}$ & RDM \\
\hline & \multicolumn{2}{|c|}{--------- \% --------- } & & & g \\
\hline 1 & $94.38 \mathrm{a}$ & $90.88 \mathrm{a}$ & $18.58 \mathrm{a}$ & $0.062 \mathrm{~b}$ & $0.019 \mathrm{a}$ \\
\hline \multirow[t]{3}{*}{2} & $32.88 \mathrm{~b}$ & $30.12 \mathrm{~b}$ & $5.54 \mathrm{~b}$ & $0.223 \mathrm{a}$ & $0.018 \mathrm{a}$ \\
\hline & SDM & SEDM & SL & RL & SEL \\
\hline & \multicolumn{2}{|c|}{--------- g --------- } & -------- & ---- cm & ------- \\
\hline 1 & $0.0304 \mathrm{a}$ & $0.049 \mathrm{a}$ & $4.96 \mathrm{a}$ & $3.20 \mathrm{a}$ & $7.97 \mathrm{a}$ \\
\hline 2 & $0.0304 \mathrm{a}$ & $0.048 \mathrm{a}$ & $1.69 \mathrm{~b}$ & $2.36 \mathrm{~b}$ & $4.05 \mathrm{~b}$ \\
\hline
\end{tabular}

Tukey's test at $5 \%$ probability.

Médias seguidas pela mesma letra na coluna não diferem de acordo como teste de Tukey a $5 \%$ de probabilidade. 
and $9.8 \%$, respectively, with a variability of $93.5 \%$ (Figure 1). The application of salicylic acid attenuated the effect of salinity on the germination (ger), first germination count (fcg) and germination speed index (gsi) of the E. velutina seedlings. The higher salinity $\left(9.0 \mathrm{dS} \mathrm{m}^{-1}\right)$ prolonged the seed germination process, as observed for the average germination speed (ags), which was more related to the higher salinity and seed soaking in distilled water $(\mathrm{E} 9 \mathrm{H})$.

The dimensions of components 1 and 2 of Lot 2 (Pentecostes) were 60.6 and $24.9 \%$, respectively, with a variability of $85.5 \%$ (Figure 2). The application of salicylic acid did not attenuate the effect of salinity on the germination (ger), first germination count (fcg) and germination speed index (gsi) of E. velutina seedlings. Soaking with distilled water reduces the deleterious effects of the ECws of 3.0 and $6.0 \mathrm{dS}$ $\mathrm{m}^{-1}$ on these variables. The ECw of $9.0 \mathrm{dS} \mathrm{m}^{-1}$ and application of salicylic acid (E9SA) increased the

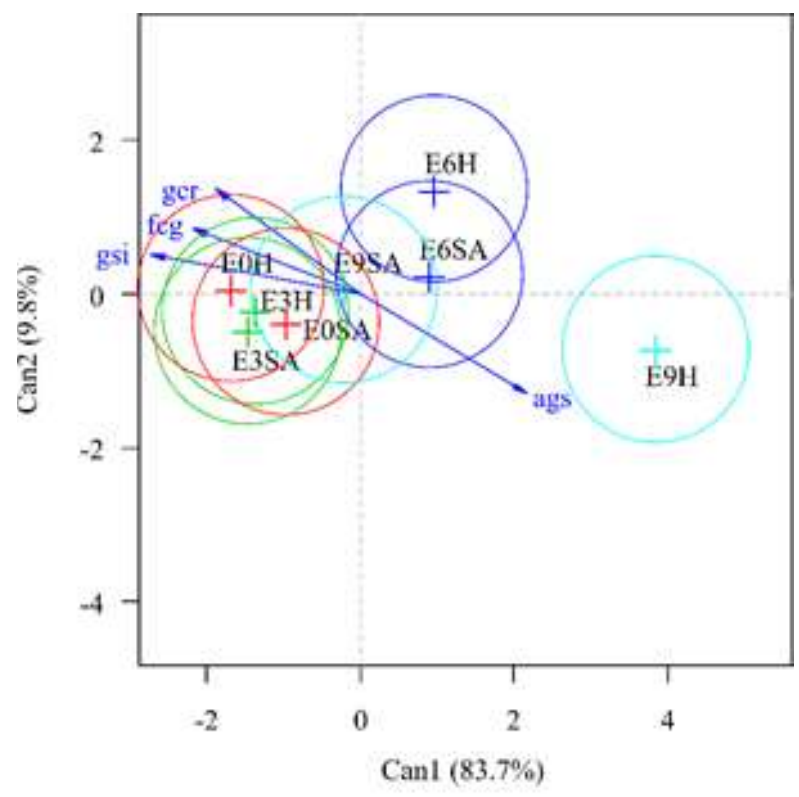

Figure 1 - Canonical variables analysis for germination percentage (ger), first count of germination ( $\mathrm{fcg}$ ), germination speed index (gsi), average germination speed (ags) of seeds in Lot 1 (Mossoró) of Erythrina velutina seeds after soaking seeds with salicylic acid and exposing them to saline stress.

Figura 1 -Análise das variáveis canônicas para porcentagem de germinação (ger), primeira contagem de germinação $\left(f_{c g}\right)$, indice de velocidade de germinação (gsi), velocidade média de germinação (ags) das sementes do Lote 1 (Mossoró) de sementes de Erythrina velutina após embebição das sementes com ácido salicílico e exposição ao estresse salino. average germination speed (ags) and, consequently, the seed germination time.

The dimensions of components 1 and 2 of Lot 1 (Mossoró) were 72.9 and 21.4\%, respectively, with a variability of $94.3 \%$ (Figure 3 ). Soaking with salicylic acid attenuated the ECw effect of $3.0 \mathrm{dS} \mathrm{m}^{-1}$ (E3SA) on root length (rl), seedling length (sel) and shoot length (sl) of E. velutina seedlings. Seed soaking with salicylic acid does not mitigate the deleterious effects of the ECws of 6.0 and $9.0 \mathrm{dS} \mathrm{m}^{-1}$ (E6SA and E9SA) on $\mathrm{rl}$, sel, sl, root dry matter (rdm), shoot dry matter ( $\mathrm{sdm}$ ) and dry mass of seedlings (sedm) of E. velutina. Severe salt stress negatively affected seedling growth, compromising its establishment.

The dimensions of components 1 and 2 of Lot 2 (Pentecostes) were 90.5 and $4.9 \%$, respectively, with a variability of $95.4 \%$ (Figure 4 ). Seed soaking with salicylic acid (E0SA, E3SA, E6SA and E9SA)

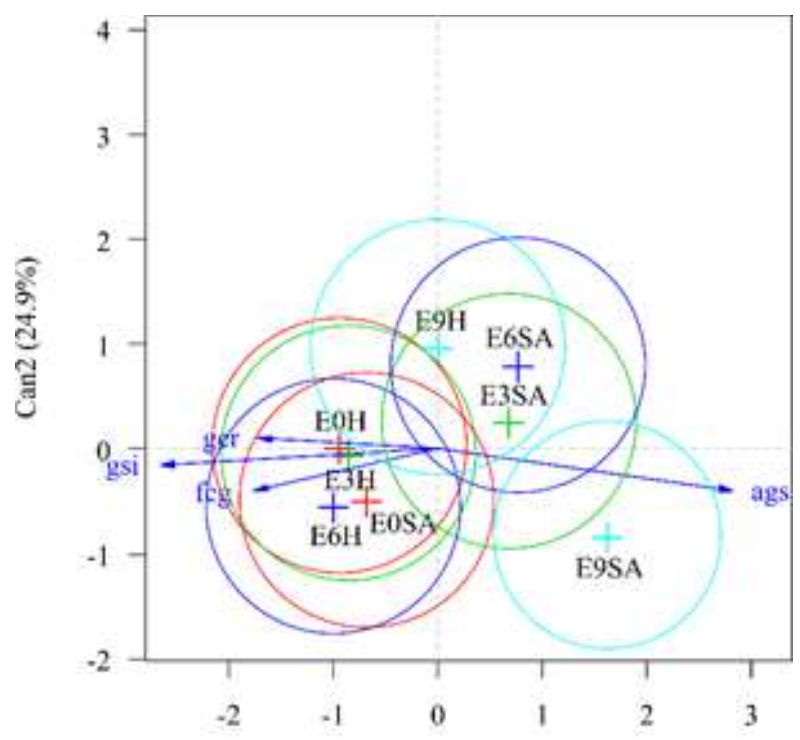

Canl $(60.6 \%)$

Figure 2-Canonical variables analysis for germination percentage (ger), first count of germination (fgc), germination speed index (gsi), average germination speed (ags) seeds in Lot 2 (Petencostes) of Erythrina velutina seeds after soaking seeds with salicylic acid and exposing them to saline stress.

Figura 2 - Análise das variáveis canônicas para porcentagem de germinação (ger), primeira contagem de germinação (fgc), indice de velocidade de germinação (gsi), velocidade média de germinação (ags) de sementes no Lote 2 (Petencostes) de sementes de Erythrina velutina após embebição das sementes com salicílico ácido e exposição ao estresse salino.

\section{Revista Árvore 2021;45:e4521}




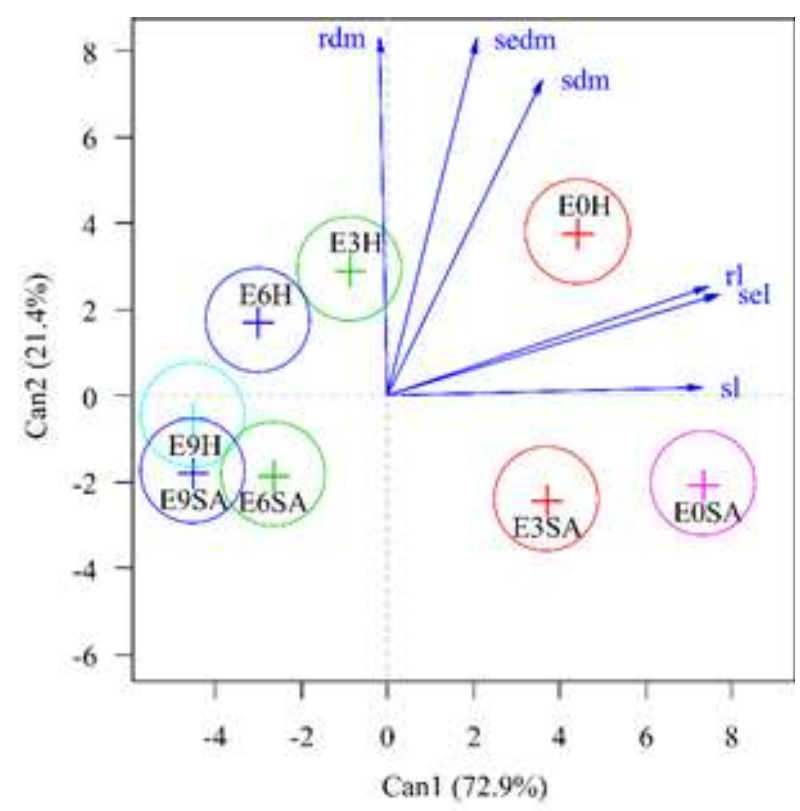

Figure 3 - Canonical variables analysis for root length (rl), shoot length (sl) and seedling length (sel), root dry mass (rdm), shoot dry mass (sdm), seedling dry mass (sedm) in Lot 1 (Mossoró) of Erythrina velutina seeds after soaking seeds with salicylic acid and exposing them to saline stress.

Figura 3 - Análise das variáveis canônicas para comprimento da raiz (rl), comprimento da parte aérea (sl), comprimento da muda (sel), massa seca da raiz (rdm), massa seca da parte aérea $(\mathrm{sdm})$ e massa seca da muda (sedm) no Lote 1 (Mossoró) de sementes de Erythrina velutina após embebição das sementes com ácido salicílico e exposição ao estresse salino.

negatively affected root length ( $\mathrm{rl}$ ), seedling length (sel), shoot length (sl), root dry mass (rdm), shoot dry mass (sdm) and seedlings dry mass (sedm) of $E$. velutina seedlings. Seed soaking with distilled water $(\mathrm{E} 0 \mathrm{H}, \mathrm{E} 3 \mathrm{H}, \mathrm{E} 6 \mathrm{H}$ and $\mathrm{E} 9 \mathrm{H})$ favored all the variables mentioned above in all levels of saline stress tested in the seeds of Lot 2.

\section{DISCUSSION}

An analysis of canonical variables was used to evaluate the association between the treatments and variables analyzed. The canonical variables analysis is the variation between treatments and variables, considering the residual dispersion of each variable, similar to the principal components analysis, but preferable when using an experimental design, that is, when there are repetitions in each treatment. In addition, each canonical variable is a linear combination of the variables used (Flores et al., 2020).

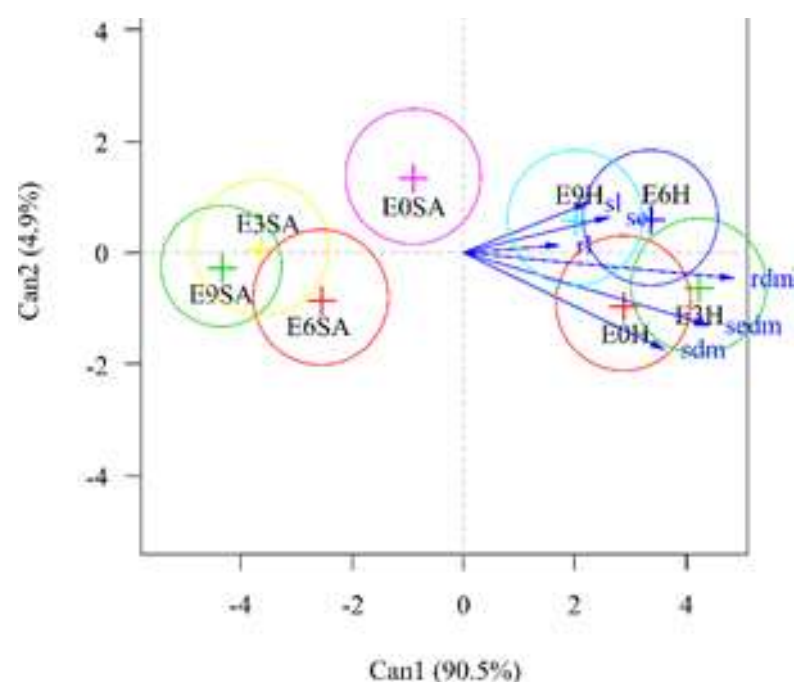

Figure 4 - Canonical variables analysis for root lenght (rl), shoot lenght (sl) and seedling lenght (sel), root dry mass (sdm), shoot dry mass (sdm), seedling dry mass (sedm) in Lot 2 (Petencostes) of Erythrina velutina seeds after soaking seeds with salicylic acid and exposing them to saline stress.

Figura 4 -Análise das variáveis canônicas para comprimento da raiz (rl), comprimento da parte aérea (sl), comprimento da muda (sel), massa seca da raiz (sdm), massa seca da parte aérea ( $\mathrm{sdm}$ ) e massa seca da muda (sedm) no Lote 2 (Petencostes) de sementes de Erythrina velutina após embebição das sementes com ácido salicílico e exposição ao estresse salino.

The physiological characterization of the mulungu seed lots demonstrated that the seeds of Lot 1 have higher physiological quality (germination and vigor) in relation to those of Lot 2 . Since the germination test is the main means for determining seed quality, it is associated with vigor tests, which are important tools for seed physiology (Delazari et al., 2016). Because it is a native species, great genetic variability is common, indicating a wide morphophysiological variation. This is capable of determining the ecological behavior of a species, and the characterization of the physiological quality of the seed lots is an important tool for determining the development of the seedling and its capacity for establishing itself (Aimi et al., 2016).

The difference in the quality of the seeds of the two different lots was related to the soaking with salicylic acid, because the seeds of Lot 1 , when submitted to soaking with salicylic acid, showed greater acclimation to the effects of saline

Revista Árvore 2021;45:e4521 
stress. Soaking with salicylic acid attenuated the deleterious effects of saline stress on germination, first germination count of seeds in the lots, where salicylic acid increased the uniformity, speed and end of germination, confirming that soaking with this phytohormone increases the resistance to saline stress. This effect is associated with the mode of action of salicylic acid in the activity of enzymes involved in germination, such as isocitrate lyase and malate, which act in the synthesis of carbohydrates and lipids during seed germination (Ababaf et al., 2019), since these enzymes are involved in the glyoxalate cycle and are able to increase tolerance during germination (Brito et al., 2020).

Although salicylic acid favored seed germination, the speed of the germination process was reduced by an increase in $\mathrm{ECw}$, due to the reduction of the osmotic potential promoted by the excess of salts in the substrate, resulting in a low water absorption capacity by the seeds. In addition to ion toxicity and oxidative stress, it induces the production of ROS (reactive oxygen species), which promote the denaturation of proteins, lipids and nucleic acids, with structural changes in the tissues of the seeds (Lai et al., 2020).

The vigor of mulungu seedlings from Lot 1 was stimulated by soaking the seeds with salicylic acid, indicating the effectiveness of this phytohormone in increasing the species tolerance to stress conditions, as evidenced by Nóbrega et al. (2020) in Mesosphaerum suaveolens seedlings. This is related to the action of salicylic acid in stimulating systemic resistance to the damage caused by saline stress, reducing the toxicity of ions (mainly $\mathrm{Na}^{+}$) and the water restriction imposed by the reduction of osmotic potential (Gharbi et al., 2018). This indicates that salicylic acid attenuates the damage caused by salinity, since this phytohormone promotes gene expression, increasing the activity of protective osmolytes which induce the regulation of osmotic potential (Kamram et al., 2020).

Seeds from Lot 2 were inferior in physiological quality. They were not affected by soaking with salicylic acid. The action that this phytohormone provides may have variability, where it will not always have a beneficial effect, and the effects may vary depending on genetic factors, such as species, cultivar and varieties (El-Esawi et al., 2017). The effects on seed germination are variable, due to the molecular mechanisms involved in tolerating salt stress (Lee et al., 2010; Liu et al., 2019).

Soaking of seeds with distilled water favored the vigor of $E$. velutina seedlings. This conditioning may have made the seeds absorb water, thus becoming capable of hydrating all their tissues, allowing the seed to germinate and originate vigorous seedlings, even under conditions of saline stress. The process of soaking the seed in water stimulates the activation of the germination metabolism, providing reactions in the degradation of reserves that nourish the development of the embryonic axis (Lechowska et al., 2019), resulting in seedlings with greater vigor.

However, this species is sensitive to high concentrations of salts in the initial growth phase. The initial development of plants is the most sensitive stage to salinity, due to physiological and metabolic changes, reducing water absorption by the roots and compromising the development of plants (Liu et al., 2020), as observed in crambe (Crambe abyssinica Hochst) (Silva et al., 2019) and red pereiro seedlings (Simira gardneriana MR Barbosa \& Peixoto) (Oliveira et al., 2019).

The effect of salinity damage on the initial growth of E. velutina is configured in the seedlings' dry mass, where in both lots the saline stress reduced the biomass. The behavior indicates the damage caused by the effects of saline stress on initial growth and seedling establishment. These effects were promoted by osmotic stress, which reduces the capture, absorption and compartmentalization of toxic ions in the seeds' tissues, compromising cell expansion and division (Silva et al., 2019) and, consequently, reducing the vigor of the seedlings.

\section{CONCLUSIONS}

Soaking with $1.0 \mathrm{mM}$ salicylic acid increases seed tolerance to saline conditions, stimulating the germination and vigor of E. ventulina seedlings.

\section{AUTHOR CONTRIBUTIONS}

Jackson S. Nóbrega, Ronimeire T. Silva, Maria F. Q. Lopes and Francisco R. A. Figueiredo: material preparation, data collection and text written. Toshik I. Silva: data analysis and text written. Riselane L. A. Bruno: conception and research supervision. All authors read and approved the final manuscript.

Revista Árvore 2021;45:e4521 


\section{REFERENCES}

Ababaf M, Omidi H, Bakhshandeh AM. Germination indices and antioxidant activity enzyme responses of madagascar periwinkle (Catharanthus roseus (L.) G. Don) under pretreatment by salicylic acid. Applied Ecology and Environmental Research. 2019;17(2):3989-4005. doi: 10.15666/ aeer/1702_39894005.

Aimi SC, Araujo MM, Muniz MFB, Walker C. Teste de sanidade e germinação em sementes de Cabralea canjerana (Vell.) Mart. Ciência Florestal. 2016;26(4):1361-1370. doi: $10.5902 / 1980509825155$.

Akter L, Fakir OA, Alam MK, Islam MU, Chakraborti P, Alam MJ, Rashid H, Begum M, Kader MA. Amelioration of salinity stress in maize seed germination and seedling growth attributes through seed priming. Open Journal of Soil Science. 2018;8(5):137-146. doi: 10.4236/ojss.2018.85011

Alves Junior CA, Vitoriano JO, Silva DLS, Farias ML, Dantas NBL. Water uptake mechanism and germination of Erythrina velutina seeds treated with atmospheric plasma. Scientific Reports. 2016;6(1):33722. doi: 10.1038/srep33722

Anaya F, Fghire R, Wahbi S, Loutfi K. Influence of salicylic acid on seed germination of Vicia faba L. under salt stress. Journal of the Saudi Society of Agricultural Sciences. 2018;17(1):1-8. doi: $10.1016 / \mathrm{j}$.jssas.2015.10.002

Brasil. Regras para análise de sementes. Brasília: MAPA/ACS; 2009. ISBN 978-85-99851-70-8

Brito VC, Almeida CP, Barbosa RR, Carosio MGA, Ferreira AG, Fernandez LG, Castro RD, Hilhorst H, Ligterink W, Ribeiro PR. Overexpression of Ricinus communis L. malate synthase enhances seed tolerance to abiotic stress during germination. Industrial Crops and Products. 2020;145:112110. doi: $10.1016 /$ j.indcrop.2020.112110

Delazari P, Garlet J, Souza GF. Teste de condutividade elétrica em lotes de sementes de Schinus molle L. Floresta e Ambiente. 2016;23(3):413-417. doi: 10.1590/21798087.142615 .

Dias KCF, Almeida JC, Vasconcelos LC, Patrocinio
MLV, Barbosa TM, Ximenes NX, et al. Standardized extract of Erythrina velutina Willd. attenuates schizophrenia-Like behaviours and oxidative parameters in experimental animal models. Journal of Pharmacy and Pharmacology. 2019;71(3):379389. doi: 10.1111/jphp.13039

El-Esawi MA, Elansary HO, El-Shanhorey NA, Abdel-Hamid AME, Ali HM, Elshikh MS. Salicylic acid-regulated antioxidante mechanisms and gene expression enhance rosemary performance under saline conditions. Frontiers in Physiology. 2017;8:716. doi: 10.3389/fphys.2017.00716

Flores MS, Paschoalete WM, Baio FHR, Campos CNS, Pantaleão AA, Teodoro LPR, Silva Júnior $\mathrm{CA}$, Teodoro PE. Relationship between vegetation indices and agronomic performance of maize varieties under different nitrogen rates. Bioscience Journal. 2020; 36(5):1638-1644. doi: 10.14393/BJv36n5a2020-47993

Friendly M, Fox J. Candisc: visualizing generalized canonical discriminant and canonical correlation analysis. $\mathrm{R}$ package version 0.8-0; 2017.

Gharbi E, Lutts S, Dailly H, Quinet M. Comparison between the impacts of two different modes of salicylic acid application on tomato (Solanum lycopersicum) responses to salinity. Plant Signaling \& Behavior. 2018;13(5):e1469361. doi: $10.1080 / 15592324.2018 .1469361$

Ibrahim EA. Seed priming to alleviate salinity stress in germinating seeds. Journal of Plant Physiology. 2016;192:38-46. doi: 10.1016/j.jplph.2015.12.011.

Kamram M, Xie K, Sun J, Wang D, Shi C, Lu $\mathrm{Y}$, et al. Modulation of growth performance and coordinated induction of ascorbate-glutathione and methylglyoxal detoxification systems by salicylic acid mitigates salt toxicity in choysum (Brassica parachinensis L.). Ecotoxicology and Environmental Safety. 2020;188:109877. doi: 10.1016/j. ecoenv.2019.109877.

Kim Y, Mun BG, Khan AL, Waqas M, Kim HH, Shahzad R, Imram M, Byung-Wook Y, Lee IJ. Regulation of reactive oxygen and nitrogen species by salicylic acid in rice plants under salinity stress conditions. Plos One. 2018.13(3):e0192650. doi: 10.1371/journal.pone.0192650

Labouriau LG, Valadares MEB. On the germination 
of seeds Calotropis procera (Ait.) Ait.f. Anais da Academia Brasileira de Ciências. 1976;48(2):263284.

Lai Y, Zhang D, Wang J, Wang J, Ren P, Yao L, et al. Integrative transcriptomic and proteomic analyses of molecular mechanism responding to salt stress during seed germination in hulless barley. International Journal of Molecular Sciences. 2020;21(1):359. doi: 10.3390/ijms21010359.

Lechowska, K, Kubala, S, Wojtyla, Ł, Nowaczyk, G, Quinet, M, Lutts, S, et al. New insight on water status in germinating Brassica napus seeds in relation to priming-improved germination. International Journal of Molecular Sciences. 2019;20(3):540. doi: 10.3390/ijms20030540.

Lee S, Kim SG, Chung-Mo P. Salicylic acid promotes seed germination under high salinity by modulating antioxidant activity in Arabidopsis. New Phytologist. 2010;188 (2):626-637. doi: 10.1111/j.1469-8137.2010.03378.x

Liu J, Li L, Yuan F, Chen M. Exogenous salicylic acid improves the germination of Limonium bicolor seeds under salt stress. Plant Signaling \& Behavior. 2019;14(10):e1644595. doi: $10.1080 / 15592324.2019 .1644595$

Liu X, Wang L, Wei Y, Zhang Z, Zhu H, Kong L, et al. Irrigation with magnetically treated saline water influences the growth and photosynthetic capability of Vitis vinifera L. seedlings. Scientia Horticulturae. 2020;262:109056. doi: 10.1016/j. scienta.2019.109056

Maguire JD. Speed of germination-aid in selection and evaluation for seedling emergence vigor. Crop Science. 1962;2(2):176-177. doi: 10.2135/ cropsci1962.0011183X000200020033x

Nóbrega JS, Bruno RLA, Figueiredo FRA, Silva TI, Silva RT, Lopes KP. Effects of irrigation water salinity and salicylic acid on germination and vigor of Mesosphaerum suaveolens (L.) Kuntze. Semina: Ciência Agrárias. 2020;41(5):1507-1516. doi: 10.5433/1679-0359.2020v41n5p1507.

Oliveira FN, Castro THS, Torres SB, Nogueira NW, Freitas RMO. Germination and initial development of Simira gardneriana M.R. Barbosa \& Peixoto (Rubiaceae) seedlings under different temperatures and salinity levels. Semina: Ciência Agrárias. 2019;40(3):1023-1032. doi: 10.5433/1679-0359.2019v40n3p1023.

Pereira IC, Catão HCRM, Caixeta F. Seed physiological quality and seedling growth of pea under water and salt stress. Revista Brasileira de Engenharia Agrícola e Ambiental. 2020;24(2):95100. doi: 10.1590/1807-1929/agriambi. v24n2p95-100.

R Core Team. R: A language and environment for statistical computing. Version 4.0.4. R Foundation for Statistical Computing; 2020.

Rodrigues DR, Silva AFD, Cavalcanti MIP, Escobar IEC, Fraiz ACR, Ribeiro PRDA, et al. Phenotypic, genetic and symbiotic characterization of Erythrina velutina rhizobia from Caatinga dry forest. Brazilian Journal of Microbiology. 2018;49(3):503-512. doi: 10.1016/j.bjm.2017.09.007.

Silva MF, Araújo EF, Silva LJ, Amaro HTR, Dias LAS, Dias DCFS. Tolerance of crambe (Crambe abyssinica Hochst) to salinity and water stress during seed germination and initial seedling growth. Ciência e Agrotecnologia. 2019;43:e025418. doi: 10.1016/j. jssas.2017.09.004.

Teixeira MG, Moraes MMD, Camara CA. Chemical profiles of essential oils and fatty acids from Erythrina velutina. Química Nova. 2019;42(1):6570. doi: 10.21577/0100-4042.20170304.

Yan Y, Pan C, Du Y, Li D, Liu W. Exogenous salicylic acid regulates reactive oxygen species metabolism and ascorbate-glutathione cycle in Nitraria tangutorum Bobr. under salinity stress. Physiology and Molecular Biology of Plants. 2018;24(4):577-589. doi: 10.1007/s 12298-018-05405.

Revista Árvore 2021;45:e4521 